\title{
L.G. Keush
}

\section{THE FORMATION OF FRACTAL CARBON STRUCTURES IN THE PLASMA ARC DISCHARGE}

\author{
National Metallurgical Academy of Ukraine \\ 4 Prospect Gagarina, Dnipropetrovsk,49600,Ukraine,E-mail: lina.keush@yandex.ua
}

\begin{abstract}
Fractal structures are common in nature, and the structures that play a role in the formation of macroscopic systems, as well as represent new structures characterized by dramatic changes in the physical properties. The aim of this work is to determine the dimensions of fractal carbon structures using electron microscopy and provision characteristics of fractal carbon structures by calculating the fractal dimension.

The feedstock for fractal structures in an arc discharge is a mixture of pyrolytic carbon and coal tar. The fractal carbon structures has been systematically studied by scanning electron microscopy (SEM) and transmission electron microscopy. The SEM observation shows quite a large range of sizes of fractal clusters and aggregates. The TEM analysis reveals formation of carbon nanoparticles in a narrow range of 2-8 $\mathrm{nm}$.

The results show that the fractal structure of the carbon deposits are volumetric fractals with dimension of carbon deposits of 2.96. Volume fractal structure consisting of fractal aggregates, the cloud formations, and the like ones having a similar structure may be formed of different materials - graphite and pyrolytic carbon. A necessary condition for the nucleation of carbon nanostructures is the formation of carbon nanoparticles in an arc discharge.
\end{abstract}

Keywords: fractal aggregates, fractal clusters, plasma arc discharge, carbon deposit

\section{INTRODUCTION}

Interest in fractal structures can be aroused by several factors. Fractal structures are common in nature, and the structures that play a role in the formation of macroscopic systems, as well as represent new structures characterized by dramatic changes in the physical properties. Solids considered fractals, if there is a geometric similarity in the structure of the solid. These structures are formed by condensation under complex non-equilibrium conditions, an example would be the adhesion of solid particles moving according to a certain law [1]. The analysis of fractal clusters and aggregates reduced to compare the properties of geometrically determined fractal structures (scale invariance, similarity, structural hierarchy, etc.) with the structural formations in solids [2]. Fractal structures formed of carbon nanoparticles can enhance the field emission. It was experimentally shown $[3,4]$ that the thermal EMF of a fractal carbon structure, obtained by atomizing graphite in the plasma of an arc discharge, increased almost by an order of magnitude compared to that of the graphite. In many cases, the fractal structure of a solid allows higher specific strength characteristics, low thermal conductivity and acoustic permeability.

In the plasma-arc method for producing carbon nanotubes, carbon nanoparticles, and fractal carbon structures electrodes of graphite are often used [5-7]. Fractal structures in the cathode deposit consist of spherical carbon clusters with size of 6-8 nm, which merge and can give structure sizes of diameters.

The aim of this work is to determine the dimensions of fractal carbon structures using electron microscopy and to provide characteristics of fractal carbon structures by calculating the fractal dimension.

\section{EXPERIMENTAL PART}

We obtained a carbon deposit when atomizing an electrode in the plasma-arc synthesis chamber shown in Fig. 1, where the inert gas (argon) fed and the pressure maintained at the level of $69 \mathrm{kPa}$. The reactor for carbon nanomaterials works as follows. Two electrodes: rolling anode 2 attached to the water-cooled cathode holder 3 and 4, located in the plasma reactor 1 . The inert gas supplied through the special channels 5 . Temperature in the area of the arc is high enough to ionize argon and therefore, supply the inert gas directly through the special through-channels 5 in cathode 4 to support the generation of arc. The role of inert gas also is, firstly, in cooling carbon fragments, as excited they are not going in stable nanostructures, and, secondly, in assigning energy that is released when connecting fragments. The apparatus walls are 
cooled by means of cooling water circulating through pipes 7 and 8 . The duration of the experiment of carbon nanomaterials synthesis by arc discharge usually is about $30-40 \mathrm{~min}$, bringing the camera settles on the walls of the fullerene soot (plus fullerenes) and a solid cylindrical sediment on cathode rods 9. It is a central part of the deposit containing carbon nanostructures, nanoparticles and always accompanied by a certain number of disordered carbon.

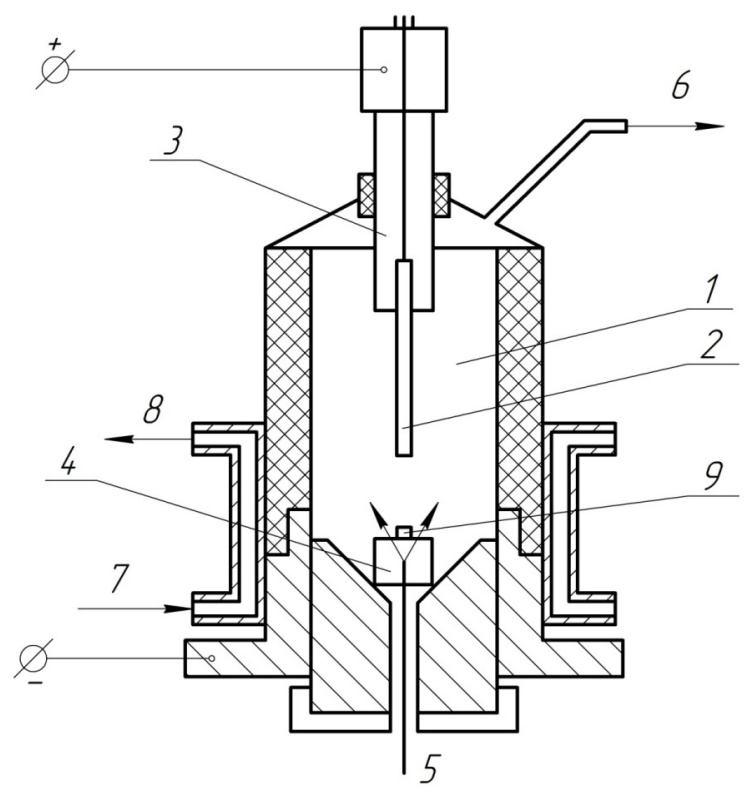

Fig. 1. The design of a plasma-arc reactor: 1 - plasma reactor; 2 - movable anode; 3 - water-cooled holder; 4 - cathode; 5, 6 - through channels for the supply of inert gas; 7 - water inlet pipe; 8 water outlet pipe; 9 - carbon deposit

The electrode that atomized in the chamber had a certain composition, the length of $80 \mathrm{~mm}$ and the diameter of $10 \mathrm{~mm}$. The electric current measured was $80-90 \mathrm{~A}$ at a voltage of $20-30 \mathrm{~V}$. The evaporation time of the upper electrode (anode) and the time of formation of the deposit on the lower, fixed electrode (cathode) was $30 \mathrm{~min}$. The cathode consisted of a mixture of the pyrolytic carbon and the coal tar. Under these conditions, the structure of the substance was formed either in the process of recovery of the system from the nonequilibrium state or under non-equilibrium conditions at all. The plasma was formed in the inter electrode gap, and within $10^{-4} \mathrm{~s}$ nanoparticles were synthesized, which gave rise to the formation of fractal structures either through the mechanism of cluster-cluster aggregation or of diffusionlimited aggregation $[8,9]$. The resulting electrode deposit was silvery in color. The direct current density was $11.3-12.7 \mathrm{~A} / \mathrm{cm}^{2}$.

After completion of the arc discharge, we have collected the deposit formed during the synthesis of a plasma arc reactor at the cathode. The surface of the deposit was studied using scanning electron microscopy (SEM) with an electron microscope Jeol JSM $5800 \mathrm{LV}$. The accelerating voltage was $20 \mathrm{kV}$.

The analysis and measurement of linear dimensions of images were performed using the program Altami Studio 3.4.

\section{RESULTS AND DISCUSSION}

In Fig. $2 a$, an image of the carbon deposit is shown obtained with a scanning electron microscope. In the process of formation of the carbon deposit, fractal clusters of 5-7 $\mu \mathrm{m}$ form «cloud-like» fractal aggregates of $80 \mu \mathrm{m}$. Quite huge fractal clusters of $20-40 \mu \mathrm{m}$ in size that form fractal aggregates of $157 \mu \mathrm{m}$ are also available.

In Fig. $2 b$, the carbon deposit is represented, which features continuous fractal clusters of $1.5-11 \mu \mathrm{m}$ and fractal aggregates of $30 \mu \mathrm{m}$ in size.

In Fig. $2 c$ and Fig. $2 d$, it is seen that the cathode structure is very porous and is composed of layers of laminas, one side of which features fractal clusters sized from smaller than 1 to $5 \mu \mathrm{m}$. From these pictures, it can assumed that the fractal structures come into being on the surfaces that have a very porous structure, as well as in the process of the plasma-arc discharge, where structural defects appeared on the cathode surface. As a result, the substance precipitates more quickly on the defects and consequently fractal structures are formed.

The carbon deposit was also obtained through the plasma arc discharge on the graphite cathode. The voltage maintained at the level of $40-50 \mathrm{~V}$. The electric current was $90 \mathrm{~A}$. The evaporation time of the upper electrode (anode) and the time of the formation of the deposit on the lower, fixed electrode (cathode) was $40 \mathrm{~min}$. The current density was $30 \mathrm{~A} / \mathrm{cm}^{2}$. This cathode is characterized by a more dense structure as compared to the pyrolytic carbon cathode. In this experiment, the electric current density was higher in comparison with that, where the pyrolytic carbon cathode was used. The plasma temperature in the reactor reached approximately $3200 \mathrm{~K}$.

Fig. 3 shows the obtained layered fractal aggregates ranging from 107.2 to $273 \mu \mathrm{m}$ in size. It is possible that it was an increase in the electric 
current density and temperature in the reactor that resulted in the formation of layered fractal clusters and aggregates.

The formation of fractal structures consists in the process whereby carbon atoms of the atomized electrode acquire an electric charge in the electron plasma. This process also involves nanoparticles of $2-8 \mathrm{~nm}$ in size (Fig. 4), which form continuous clusters, their dimensions being limited by the Coulomb blockade. One part of the globular clusters has a structure of amorphous carbon while the other represents multilayered

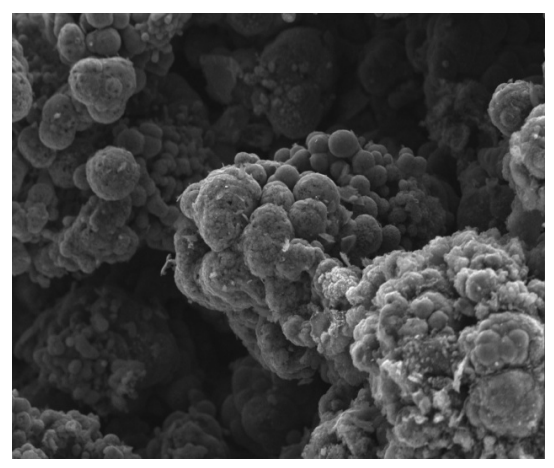

$a$

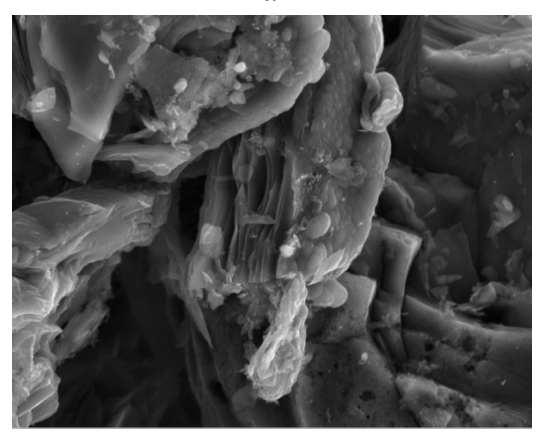

$c$ spherical structures. Globular and continuous clusters serve as the basic materials for the formation of aggregates of $0.3-0.6 \mu \mathrm{m}$, which are the basis for building «cloud-like» structures of 5-7 $\mu \mathrm{m}$ in size (Fig. $2 a$ ), which are, in turn, the basis for shaping a structure resembling a «cauliflower head» (Fig. 3). When examining the structure of the carbon deposits obtained, it can be noted that this structure formed through a selforganized process, the above structure being selfsimilar and hierarchical.

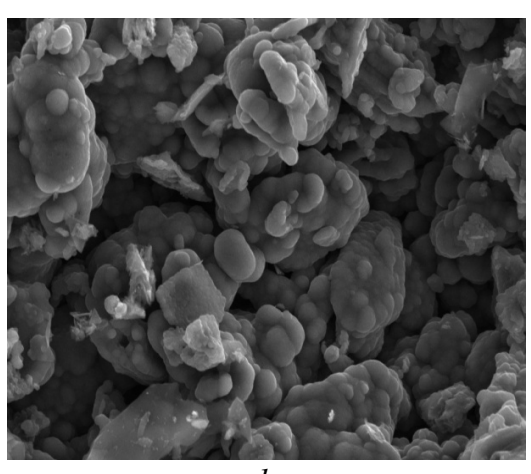

$b$

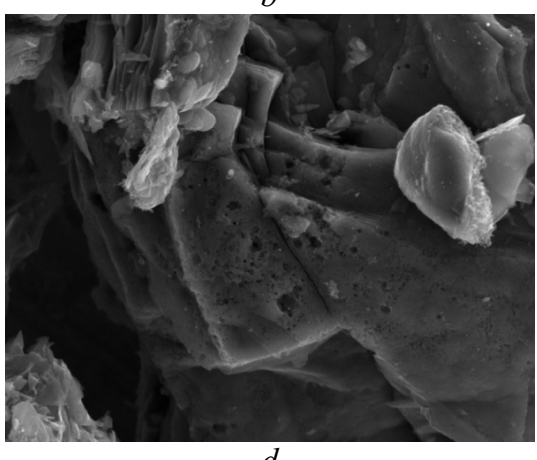

$d$

Fig. 2. SEM pictures of the carbon deposit with fractal structures formed on the pyrolytic carbon cathode (SEM, $a-\times 300, b-\times 1000, c-\times 1500, d-\times 1000)$

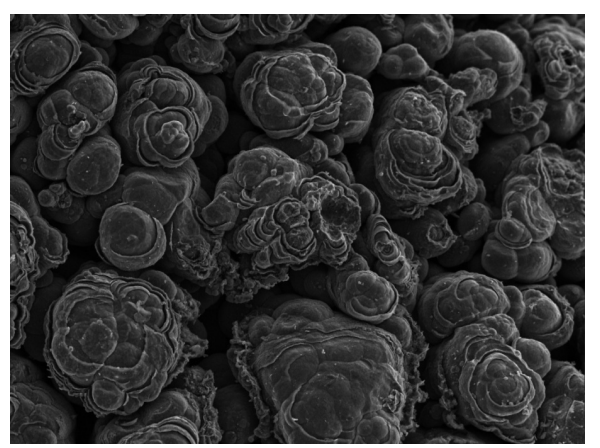

Fig. 3. SEM picture of the carbon deposit with fractal structures formed on the graphite cathode (SEM, $\times 100$ )

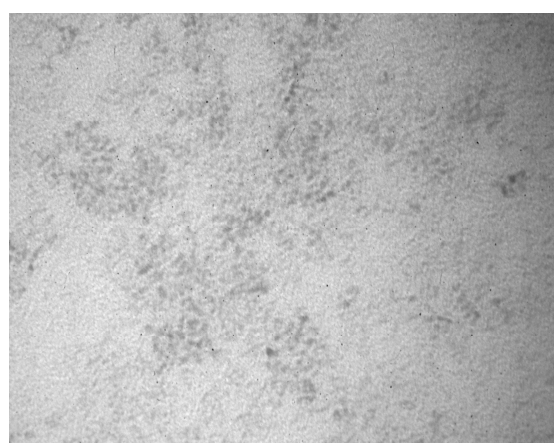

Fig. 4. TEM picture of carbon nanoparticles $($ TEM, $\times 80000)$ 
For those structures to be obtained, the availability of certain conditions was also important: the substance concentration gradient, the electromagnetic field and the substance interaction with the field. As the intensity of the electromagnetic field around defects is usually higher, the substance precipitates faster there and fractal structures come into being [8].

One of the most important characteristics of a fractal structure is the fractal dimension. To calculate this value, a model of fractal aggregates was used $[10,11]$. The said aggregates consisted of clusters having a radius of $r_{o}=1.4 \cdot 10^{-3} \mathrm{~cm}$, radius of a fractal aggregate of $R=23.8 \cdot 10^{-3} \mathrm{~cm}$, density of the carbon deposit of $\rho=2.026 \mathrm{~g} / \mathrm{cm}^{3}$ and a graphite density of $\rho_{o}=2.270 \mathrm{~g} / \mathrm{cm}^{3}$. With the radius of a fractal aggregate $\mathrm{R} \gg r_{w}$, the number of clusters is defined as:

$N(r)=\left(R / r_{0}\right)^{D}, 1<D<3$

where $D-$ the fractal dimension. From (2), the expression follows for the density of the substance within radius $R$ :

$\rho=\rho_{0}\left(r_{0} / R\right)^{\Xi-D}$

where $\rho$ - the density of the carbon deposit.

On the basis of the experimental data regarding the density of carbon deposits, as well as the radius of fractal aggregates, the fractal dimension was determined, which stands at $D=2.96$.

Typically, aggregates, built by the help of chains of spheres, without overlapping, fractal dimension $1 \leq D \leq d$. $D$ is not an integer and is between 1 and 3 ( 3 - in this case, the embedding space dimension) [12]. Hence, the structure of the carbon deposit obtained in the plasma of the electric discharge is a fractal one.

Radius of a fractal aggregate, adopted by the authors, is an indicative value, since the fractal structures of the carbon deposit obtained in an arc discharge are not spherical bodies. Nevertheless, the calculated value is close to reality and can serve as a characteristic of the production of carbon fractal structures. By reducing the relative size of individual clusters, the value of the fractal dimension $D$ is committed to 3 , which may mean increase in the density of filling the space with carbon clusters [13].

The microhardness of such fractal carbon deposits exceeds that of the graphite by 1 to 2 orders of magnitude while the density thereof constitutes 59-61\% that of the graphite [2].

\section{CONCLUSIONS}

The results show that the fractal structure of the carbon deposits are volumetric fractals whis dimension of carbon deposits is 2.96. Volume fractal structure consisting of fractal aggregates, the cloud formations, and the like ones having a similar structure may be formed of different materials - graphite and pyrolytic carbon. A necessary condition for the nucleation of carbon nanostructures is the formation of carbon nanoparticles in an arc discharge.

\title{
Утворення фрактальних вуглецевих структур у плазмо-дуговому розряді
}

\author{
Л.Г. Кеуш
}

Наиіональна металургійна академія України

проспект Гагаріна, 4, Дніпропетровськ, 49600, Україна, lina.keush@yandex.иа

\begin{abstract}
У роботі розглядається утворення фрактального вуглецевого осаду при випаровуванні електрода в плазмі дугового розряду. Наведено дані розрахунку фрактальної розмірності і розміри фрактальних кластерів та агрегатів. Такі структури мають схожу будову і утворюються на поверхні дефектів і пор.
\end{abstract}

Ключові слова: фрактальні агрегати, фрактальні кластери, плазмо-дуговий розряд, вуглецевий депозит 


\title{
Образование фрактальных углеродистых структур в плазменно-дуговом разряде
}

\author{
Л.Г. Кеуш \\ Начиональная металлургическая академия Украинь \\ проспект Гагарина, 4, Днепропетровск, 49600, Украина, lina.keush@yandex.ua
}

\begin{abstract}
В работе рассматривается образование фрактального углеродного осадка при испарении электрода в плазме дугового разряда. Приведены данные по расчету фрактальной размерности и размерам фрактальных кластеров и агрегатов. Такие структуры имеют сходное строение и образуются на поверхности дефектов и пор.
\end{abstract}

Ключевые слова: фрактальные агрегаты, фрактальные кластеры, плазменно-дуговой разряд, углеродный депозит

\section{REFERENCES}

1. Zolotukhyn Y.V. Fractals in solid state physics. Soros Educational Journal.1998.7:108. [in Russian].

2. Likharev K.K. Single-Electron devices and there application. Proc. of the JEEE. 1999. 87(4): 606.

3. Zolotukhyn Y.V., Holev Y.M., Popova A.A., Yevlev V.P. Thermoelectric properties of carbon nanotubes and fractal deposits. Tech. Phys. Lett. 2002. 28(16): 32. [in Russian].

4. Zolotukhyn Y.V., Kalynyn Yu.E., Lohynova V.Y. Solid fractal structures. Carbon nanostructures reneshable for energy. Nanosystems: synthesis, properties, and application. 2005. 9: 56. [in Russian].

5. Zolotukhyn Y.V., Sokolov Yu.V., Yevlev V.P. Structure, internal friction and modulus fractional carbon deposit. Solid State Phys.1998. 40(3): 584. [in Russian].

6. Sokolov Yu.V., Zhelezyy V.S. Fractal structure of carbon deposit obtained by sputtering of graphite in an electric arc. Tech. Phys. Lett. 2003. 29(8): 91. [in Russian].

7. Meakin P. Formation of fractal clusters and networks by irreversible diffusion-limited aggregation. Phys. Rev. Lett. 1983. 51: 1119.

8. Sokolov Yu.V. Preparation, structure, and some physical properties of the carbon deposit, iron and chromium, having a fractal structure. Tech. Phys. Lett. 2006. 32(12): 51. [in Russian].

9. Zolotukhyn Y.V., Sokolov Yu.V. Fractal structure and some physical properties of the carbon deposit obtained by sputtering a graphite in an electric arc. Tech. Phys. Lett. 1997. 23(13):71. [in Russian].

10. Smyrnov B.M. Processes in plasma and gases involving clusters. Advances in Physical Sciences. 1987. 167(11):1170. [in Russian].

11. Smorhonskaya E.A., Kyutt R.N., Hordeev S.K., Hrechynskaya A.V., Kukushkyna Yu.A. On the fractal nature of the structure of nanoporous carbon obtained from carbide materials. Solid State Phys. 2000. 42(6):1141. [in Russian].

12. Zhyulen R. Fractal aggregates. Advances in Physical Sciences. 1989. 157(2): 339. [in Russian].

13. Shmalko V.M., Zelenskyy O.Y., Brahynskyy A.M. Fractal properties of the carbon deposits from the coking chamber. Him. Fiz. Tehnol. Poverhni. 2014. 5(2):152. [in Russian]. 